\title{
EmLÉKeZÉs a PATAKI diÁKRA, Bartók PÉTERRE ${ }^{\mathrm{I}}$
}

\section{Dr. Kiss Virág Eszter}

\section{$\underline{\text { DOI 10.35402/kek.2021.1.13 }}$}

Bartók Béla, a Zeneművészeti Főiskola tanára 1937. május 26-i keltezéssel levelet írt Budapestről, a Csalán út 29. szám alól (mai Bartók Emlékház) a sárospataki Angol Gimnázium Internátusa Igazgatóságának, melyben az angol ágazatról érdeklődik kisebbik fia, Péter számára. Levelét a Református Kollégium Tudományos Gyűjteményeiben őrzik. (Lgy. 1120.)

„Bartók Béla sohasem járt Patakon. De barátai, ismerősei (...) révén sok információt kapott a pataki diákéletről, a kollégium szelleméről, nevelési rendjéről, zenei törekvéseiről. Ennek köszönhető, hogy Amerikába való távozása előtt fiát, Pétert, a sárospataki kollégium gondjaira bízta” (Barsi Ernő - Szabó Ernő: A pataki kollégium zenei krónikája. Zenemükiadó Budapest, 1984., 147. old.).

$\mathrm{Az}$ Angol Internátust Gróf Klebelsberg Kuno vallás- és közoktatásügyi miniszter (1922-1931) alapította. Az Iskolakertben álló, grandiózus épületet a Református Kollégium (1531) fennállásának 400. évfordulójára rendezett ünnepségsorozaton, 1931 őszén adták át. Klebelsberg ünnepi beszédének lényegét idézem: „Mi a tartalma a sárospataki gondolatnak? Erős, meg nem alkuvó nemzeti érzésnek európai tudással való párosítása” (Maller Sándor, Klebelsberg Kuno és a Sárospataki Református Főiskola: Az angol nyelv tanításának kezdetei Patakon. Sárospatak, 1998). A „Bodrog-parti Athén”-t ez idő tájt kezdték a „magyar Cambridge”ként is emlegetni, hiszen az országban elsőként itt lehetett angol nyelvű diplomát szerezni. Az Angol Internátusban a gazdasági és szellemi elit taníttatta leszármazottait.

Sárospatak a XVI. századtól kezdődően az ország jelentős iskolavárosa. A Kollégium diákjainak XVIII. századi melodáriumai, 1782-től a kórus szervezett müködése, a XVIII. század végétől dokumentált népdalgyüjtések a tanúi annak, hogy a „pataki szellem” a zenei életet is áthatotta.

1 A cikk napvilágot látott a Parlando 2021/2. számában is. http://www.parlando.hu/2021/2021-2/Kiss_Virag_ Eszter.pdf. Általában párhuzamos másodközlésre ritkán vállalkozunk, de köszönjük szerzőnk szíves felajánlását, hogy folyóiratunk művészeti számához írását rendelkezésünkre bocsátotta!
A leendő diák, Bartók Péter 1924-ben született Budapesten, édesapja második házasságából. Tizenhat éves korától, 1940. szeptemberétől volt az Angol Internátus diákja. Ekkor Dr. Szabó Ernő (1904-1982) volt az intézmény ének-zene tanára, aki működése idején felvirágoztatta Patak zenei életét. „A zenei nevelést a valódi magyar népdal, az általa inspirált új magyar műzene $s$ az európai műzene

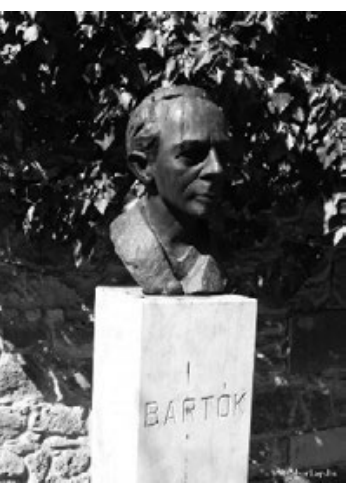

Bartók Béla szobra Sárospatakon a Szent Erzsébet utcán áll.

Kárpáti Éva alkotása (1997)

https://www.kozterkep. bu/4768/bartokbela\#vetito=19012) értékeinek alapjára kell helyezni" - vallotta. (BarsiSzabó Ernő, uo. 137. old.)

Bartók Péter nem vett Patakon hangszeres órákat. Zenei nevelését elemista korától tizenöt éves koráig maga az édesapja végezte, aki hatkötetes Mikrokozmosz sorozatának második kötetét neki ajánlotta. Dr. Szabó Ernő így írt tanítványáról: „Bartók Péter szerény, kedves diák volt, tanárai és diáktársai egyaránt szerették. Kapcsolatok szövődtek közte és az új magyar zene fiatal pataki hívei között" (uo., 147. old.). Így Vitányi Ivánnal is, aki egykori iskolatársként emlékezik $A$ küszöbember címủ művében (Noran Libro Kiadó, 2014. Eszmélkedésem-1.) Dr. Szabó Ernőre és Bartók Péterre: „Patakon Szabó Ernő zenetanárhoz, a nagyhírủ hegedűoktatóhoz kerültem [...] Ernő bácsi tanította az iskolában is a zenetörténetet. Ez is pataki specifikum, úgy tudom, sehol máshol nem volt, hogy középiskola tanulóit igazi zenetörténeti kurzusban részesítsenek. Ötödikben aztán szó került Bartókról és Kodályról. Ernő bácsi lelkes hívük volt. Elmagyarázta munkásságukat, a népdalgyüjtés megindítását, Bartók magyarságát és egyben modernségét. Illusztrációként lemezeket tett fel". 

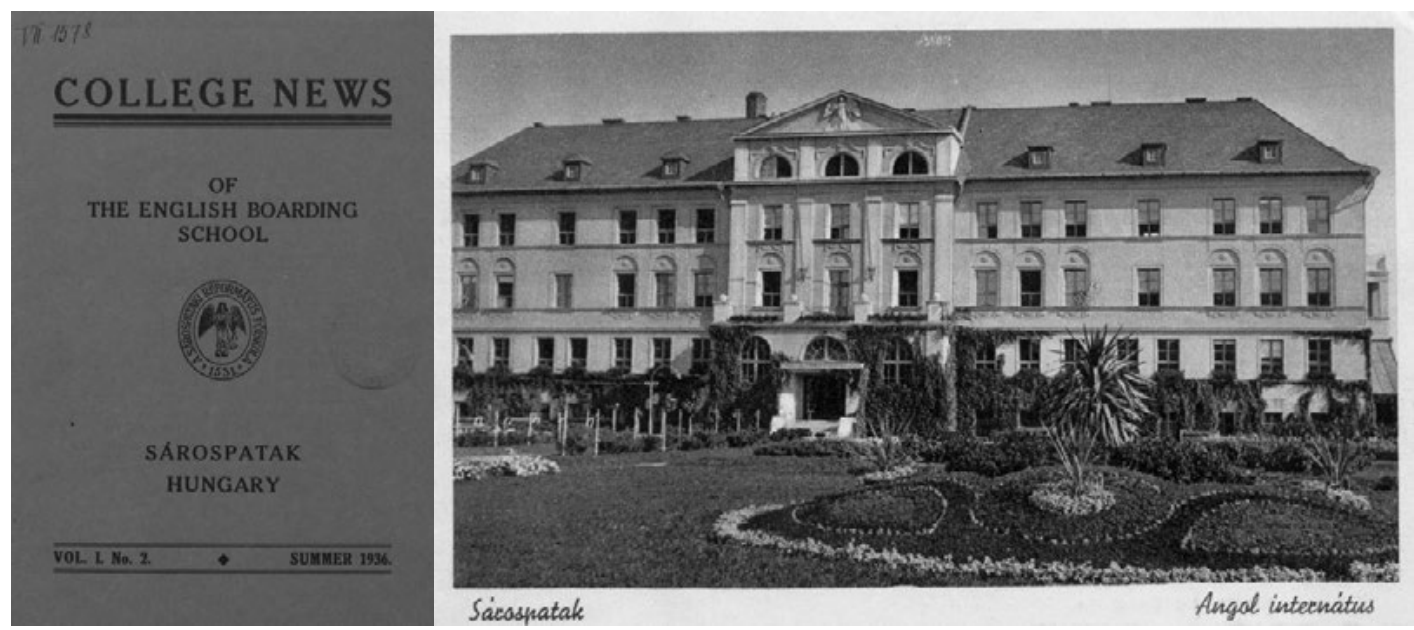

\section{Találkozás Bartók Péterrel}

„Az iskolakertben egy Bartók-kottával a hónom alatt mentem hazafelé, egy diák megállított, és rám mordult, hogy miért játszok ilyen hazafiatlan zeneszerzőt. Én kiabálva feleltem, és Bartókot a legnagyobb magyarnak neveztem. A fiú elmosolyodott, és megölelt: „A fia vagyok, Bartók Péter”. Aztán leültünk az egyik kerti padra, és hosszan elbeszélgettünk. Nem lettünk közeli barátok, de ha találkoztunk, mindig volt egymásnak mondanivalónk. Nem sok másikat találtam azonban iskolatársaim közül, akivel Bartókról beszélgethettem” (uo.).

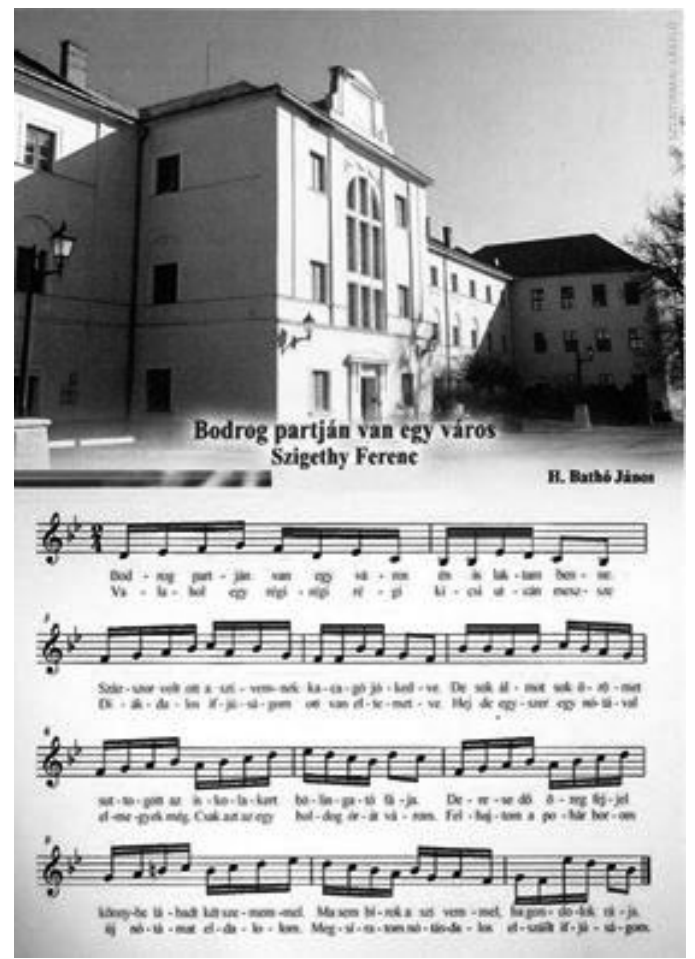

Bartók Péter szülei, Bartók Béla és Pásztory Edith 1940 októberében utaztak Amerikába. A viszontlátás ideje bizonytalan volt. Péter csak bő egy évvel később 1941. december 22-én hagyhatta el Magyarországot tíz nappal azután, hogy Magyarország hadat üzent az Amerikai Egyesült Államoknak és mindössze néhány nappal hadkötelezettségének kezdete előtt.

Az Internátusról, a búcsú pillanatairól és az édesapjával való első találkozásról Amerikában így vall: „,...Számomra Sárospatak volt a harmadik gimnázium ahová jártam és ahol, úgy emlékszem, jól éreztem magam; csak sajnos rövid ideig, hiszen nem jutottam el az érettségihez.(...) Felejthetetlen emlékem, amikor 1941 decemberében el kellett hagynom Magyarországot, és legalább a fél osztály eljött a kis pataki állomásra búcsúztatni. ..." (Bartók Péter 2006. március 24-ei levele Lőrincz Szabolcshoz. Forrás: Bolvári-Takács Gábor, Megújult a Bartók Emlékház; Zempléni Múzsa, VI. évfolyam 3. szám)

Bartók Péter így ír tehát a négyhónapnyi (!) utazást követő viszontlátásról ( 1942. április 20.): „... Vonattal egyenesen New York-ba utaztam, és egy segítőkész hordár föltett a Bronxba, szüleim lakhelyére tartó metrószerelvényre. Amikor a szerelvény megállt a Columbia Egyetem megállónál, elszorult a szívem, hiszen itt dolgozott apám; nem is sejtettem, hogy ő ugyanabban a pillanatban ugyanannak a szerelvénynek egy másik kocsijába száll be. Így történt, hogy amikor a 231. utcánál taxit kerestem, taxi helyett egy fehér hajú bácsit találtam, akinek ismerős aktatáskája volt, és aki hátulról épp úgy nézett ki, mint apám. Milyen kicsi a világ”.

Bartók Béla a következőképpen mesélt erről: „A Columbiáról hazafelé metróra szálltam, s utána elkezdtem gyalogolni a 231. utcán, amikor hirtelen 
Élet az Angol Internátusban (korabeli fényképek)

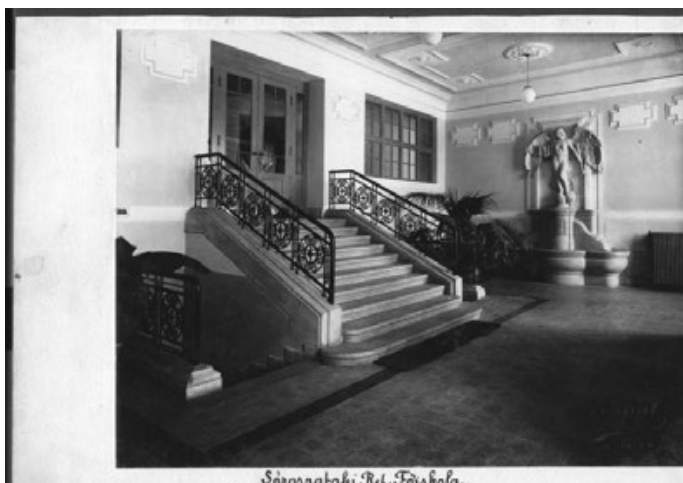

Sirospatafi Ref. Fou fola.

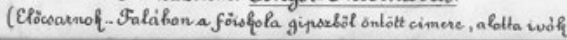
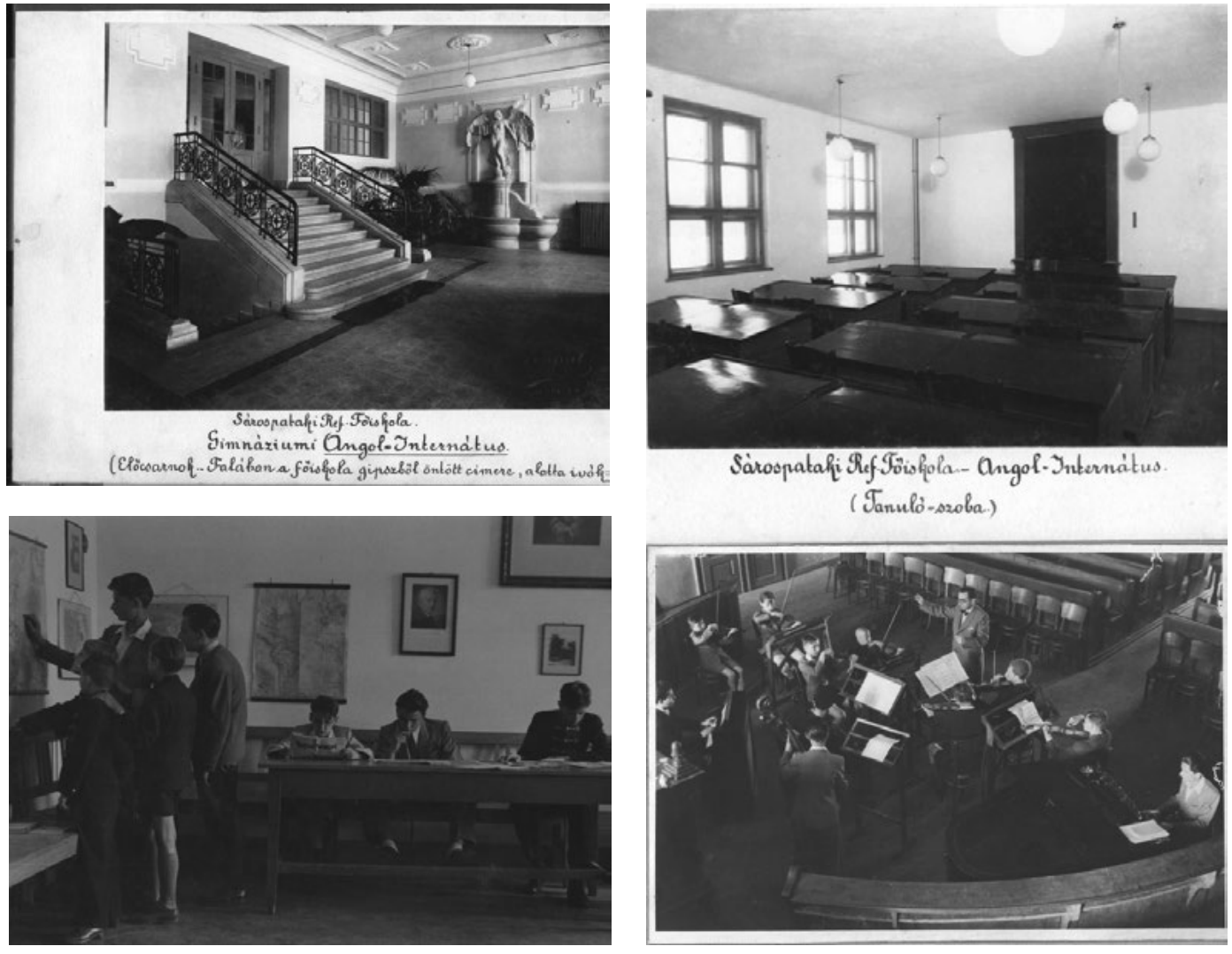

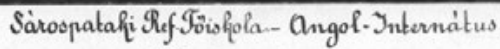
( Tanuló-szola.)
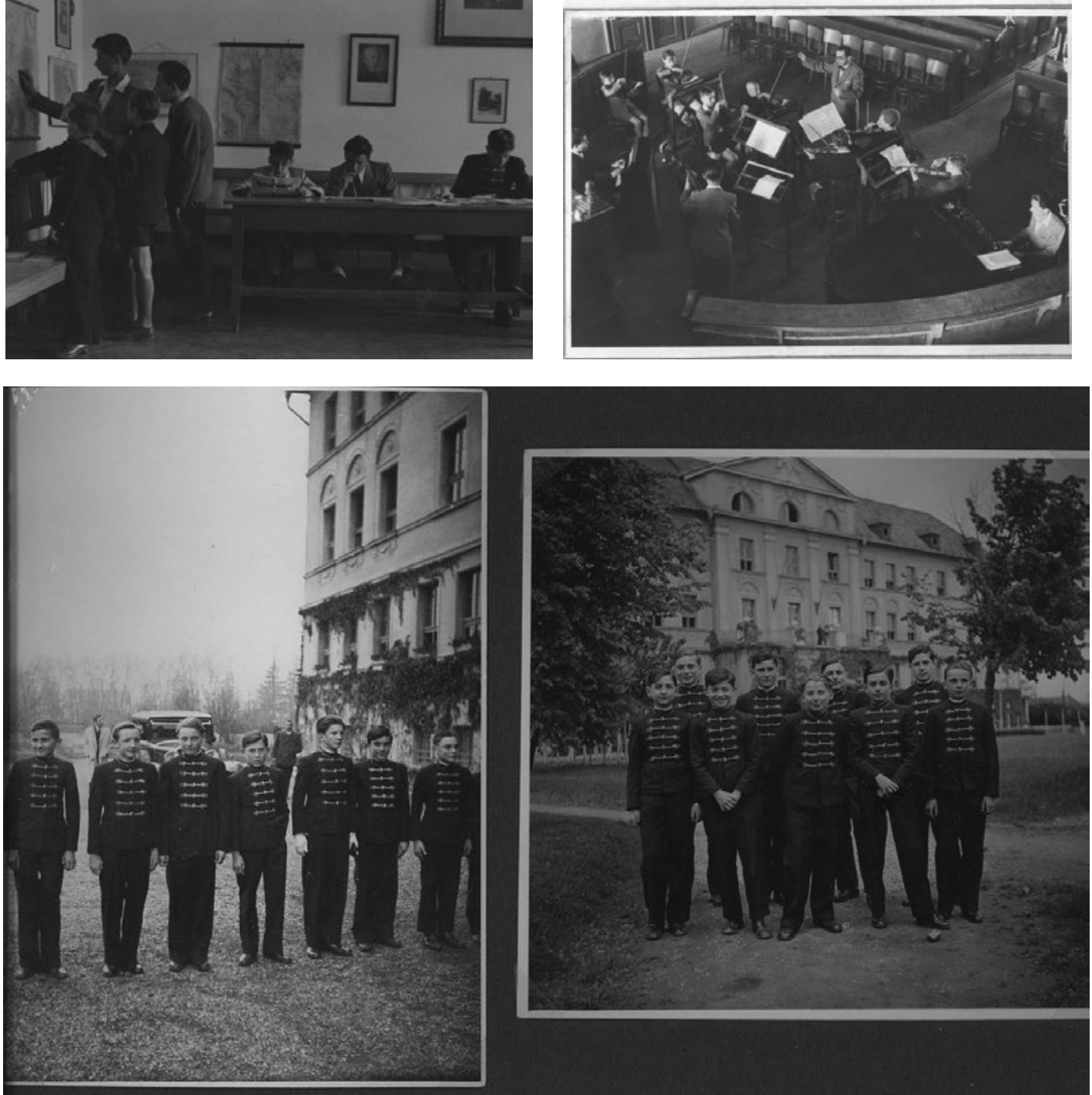

Forrás: Sárospataki Református Kollégium Tudományos Gyüjteményei 


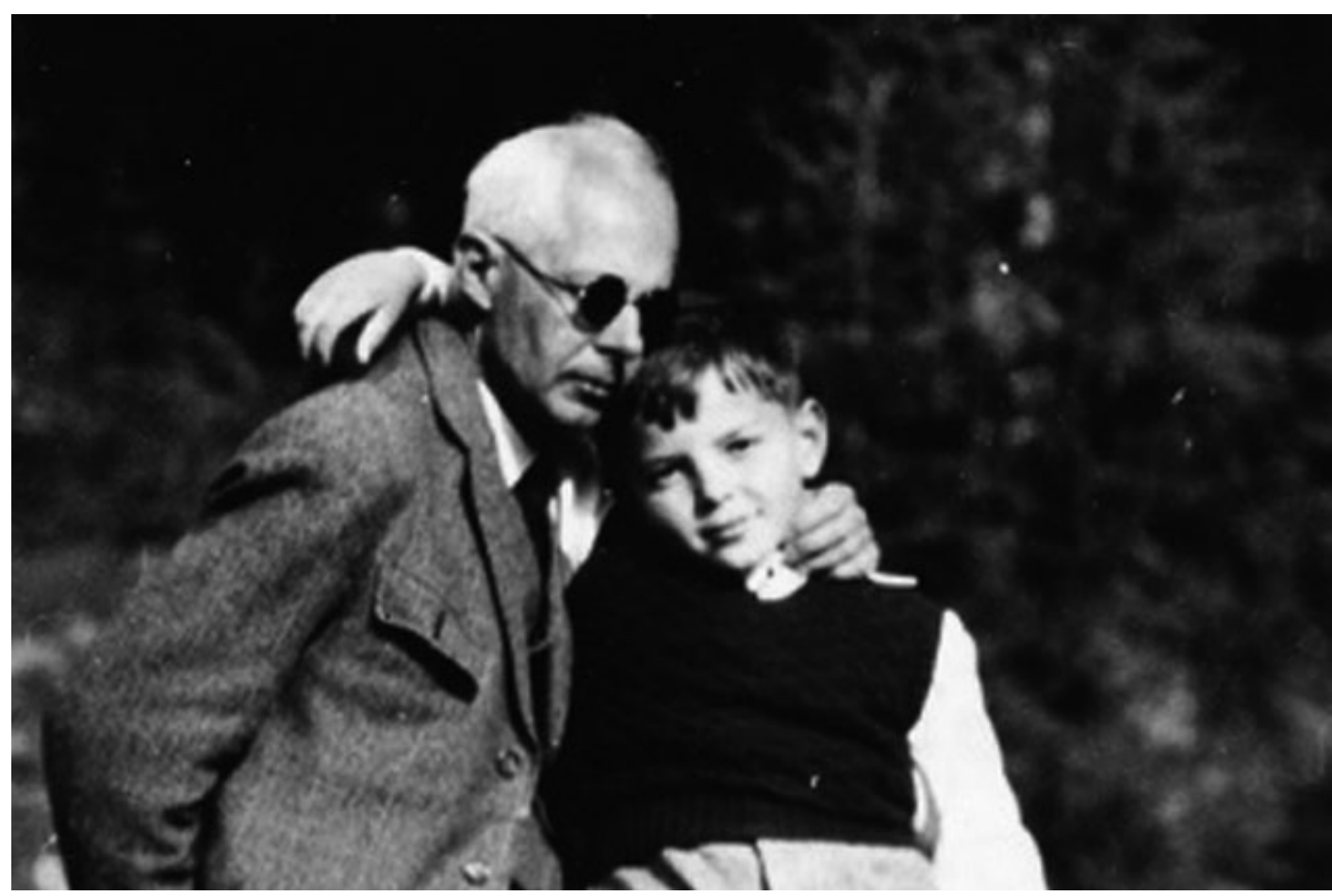

Bartók Béla és Bartók Péter

https://cultura.hulaktualis/elhunyt-bartok-bela-kisebbik-fial

egy amerikai kinézetű fiatalember toppant elém, és azt mondta: Apu!" (Bartók Péter: My Father, 87. és 85. old., Ford. Péteri Judit, EMB, Bp. 2004.)

Bartók Péter édesapja 1945. szeptember 26án hunyt el, édesanyja 1946-ban költözött haza, ő maga az Egyesült Államokban maradt és haláláig Floridában élt. Magyarságát mindvégig megőrizte.

\section{Zenei munkássága}

Édesanyja halálát követően (1982) hosszadalmas hagyatékátvételi eljárás után 1985-től Bartók Péter életét - a Bartók Records alapítója és tulajdonosaként - a Bartók művek revideált, illetve fakszimile kiadására és hangfelvételek megjelentetésére áldozta. Munkáját a hagyatékkal kapcsolatos több évtizedes pereskedés árnyékolta be. Célja - amit már nem tudott befejezni - a teljes bartóki életmű feldolgozása volt édesapja szerzői szándékának tiszteletben tartásával. A tulajdonában lévő kéziratokról saját költségen készíttetett másolatokat a Magyar Tudományos Akadémián helyezte letétbe, mindenkori hozzáférést biztosítva ezáltal a kutatók számára.

Apám című könyvével is emléket állít Bartók Bélának. A könyv által Bartók Péter gyermek- és ifjúkorába is bepillantást nyerünk a családi élet mindennapjainak tükrében.

Bartók Béla amerikai hagyatékából floridai otthonában magángyüjteményt tartott fenn. Bátyjával, ifjabb Bartók Bélával 1988-ban saját költségükre hozatták haza édesapjuk hamvait és helyezték örök nyugalomba a Farkasréti temetőben.

Sipos József rendező Bartók címmel 2017-ben készített megrázó dokumentumfilmjében is megemlékezik Bartók Péter az édesapjáról.

\section{Utóhang}

Bartók Péter földi élete 2020. december 7-én véget ért. Halálhíréről a magyar zenei- és hírmédia rövid közleményeiből értesültem. Összefoglalómat azzal a céllal írtam, hogy felhívjam a figyelmet a Bartók család sárospataki kapcsolódására, illetve írásban is kifejezzem azon szándékomat, hogy Bartók Péter tiszteletére egykori iskolájában emléktábla állítását és hangverseny rendezését kezdeményezzem Sárospatakon a 2021-es év őszére.

Számomra Bartók Péter felbecsülhetetlen zenetörténeti érték létrehozója édesapja hagyatékának gondozása, Apám címü könyvének megírása, az elkészült dokumentumfilm és riportok által. 


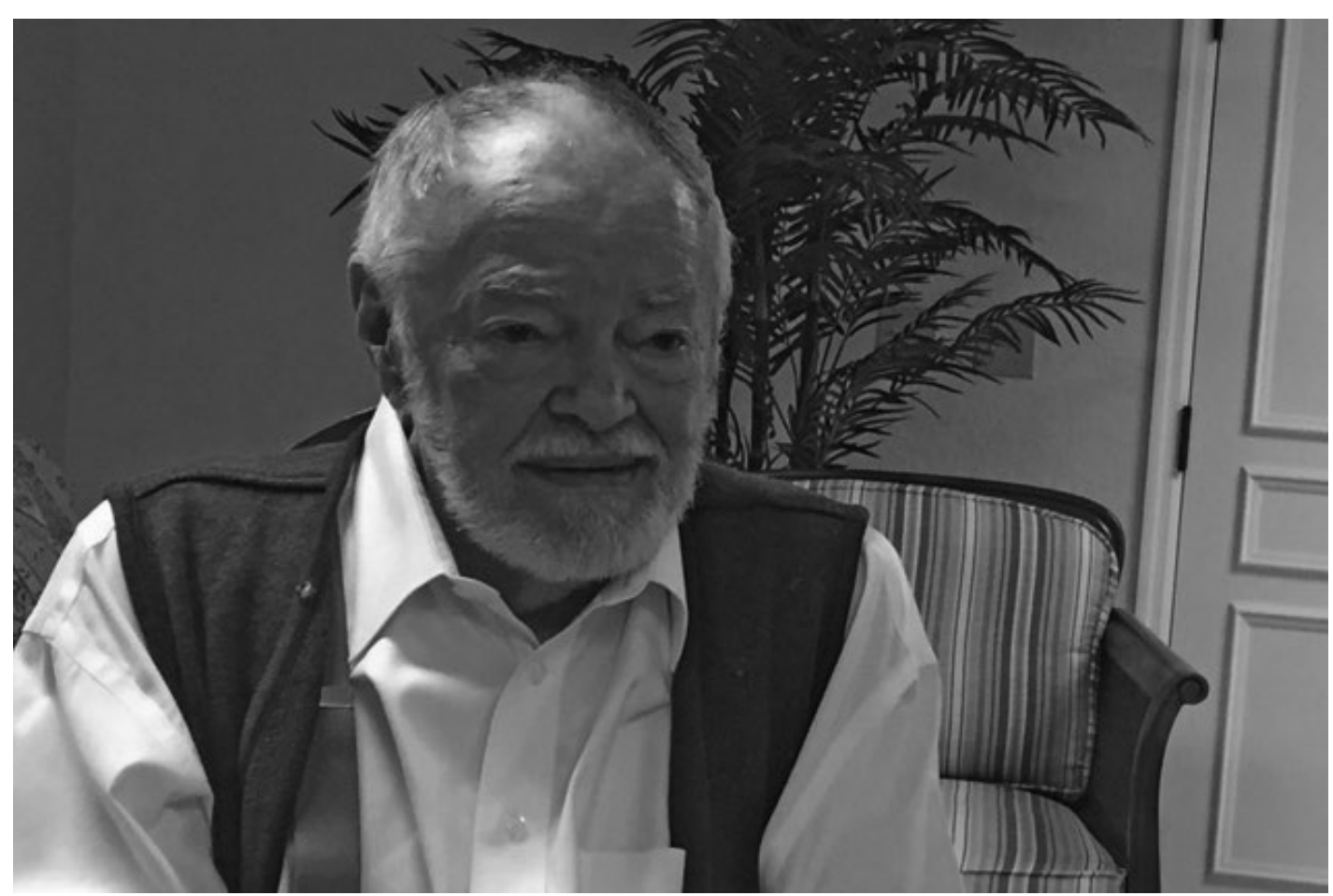

https://cultura.hulaktualis/elhunyt-bartok-bela-kisebbik-fial

Áldozatkész munkája révén - talán önmaga számára észrevétlenül - alkotó ember.

Zárásként álljon itt az Ô nyilatkozata, melyben hitvallását fogalmazta meg édesapja születésének 125., halálának 60. évfordulója kapcsán: „Soha nem vágytam a nyilvánosságra, az ünneplés pedig nem nekem, hanem apámnak szól. Én a magam módján mindig édesapámmal vagyok, minden napomat meghatározza az iránta érzett kötelességtudat. Mintha itt lenne a közelemben, és segiteni próbálna a munkámban, a Bartók müvek javitott kiadásainak elökészitésében, a kétértelmüségek megoldásában. Ha egyszer majd úgy adódik, hogy találkozunk, remélem, meg tudom indokolni, mit miért tettem, és bizom benne, hogy az esetek többségében nem helyteleniti döntéseimet" (2005). ${ }^{2}$
Isten nyugosztalja Bartók Pétert!

Köszönetet mondok Dr. Vozdvizsenszkij Vagyim Olegovics, a Sárospataki Református Gimnázium angol-orosz-francia szakos tanárának (1987-2014) és Dr. Kovács Áron, a Sárospataki Református Kollégium Tudományos Gyűjteményei munkatársának a cikk megírásában nyújtott segítségükért.

Dr. Kiss Virág Eszter zongoramüvész, egykori pataki diák 2020. december

2 Forrás: fidelio.hu/klasszikus/bartok-ecsettel-122209. html 